\title{
Building better cities: Why national urban policy frameworks matter
}

Written by: Rudiger Ahrend, Head of the Urban Programme, OECD Public Governance and Territorial Development Directorate

Last update: 3 March 2017

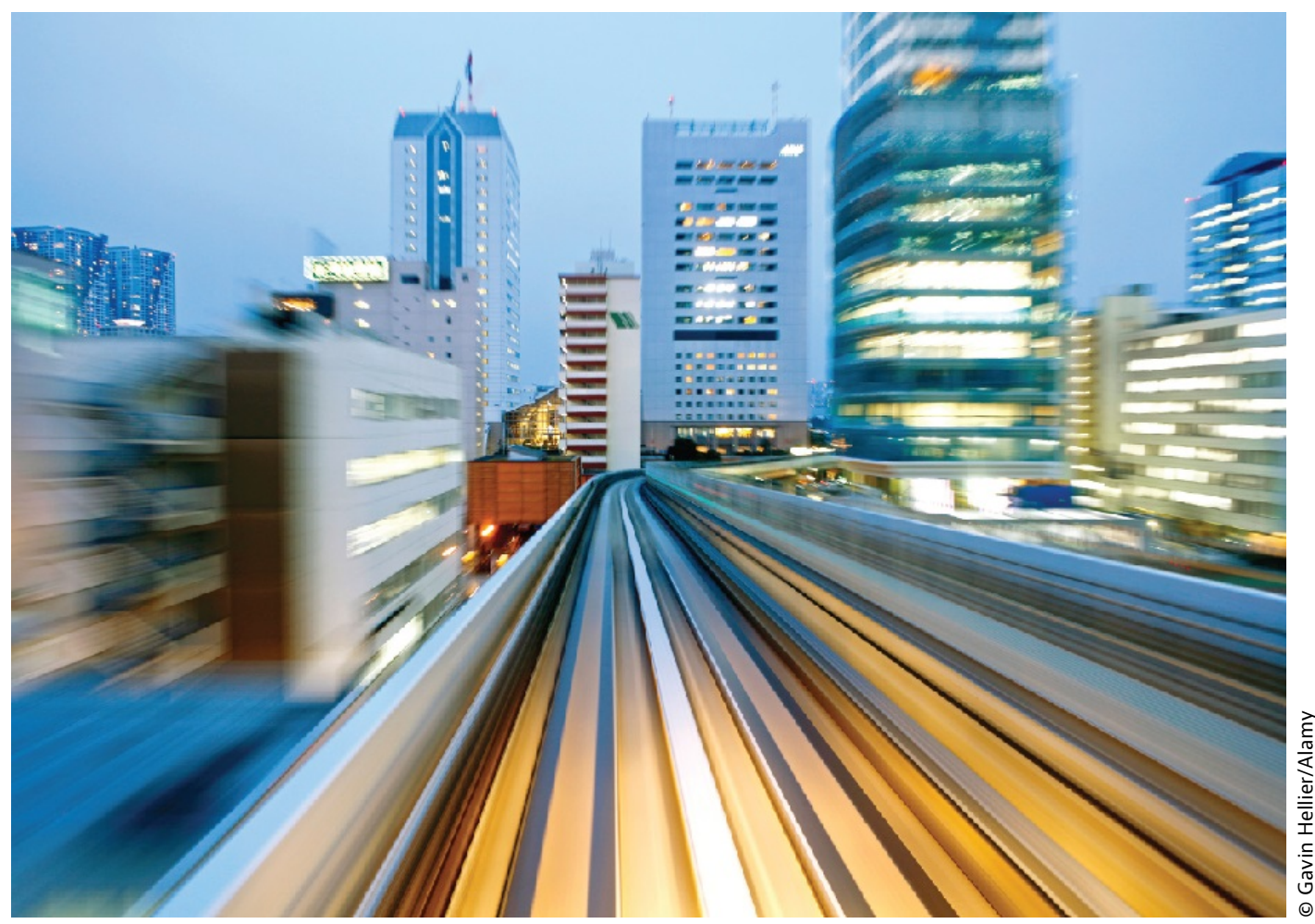

Tokyo from train in motion, not digitally altered

In 1950 New York and Tokyo were the only urban agglomerations on the planet with populations in excess of 10 million. By 2030, the number of megacities is projected to surpass 40, with seven of the world's top ten megacities in Asia. Cities of around 2-5 million are also becoming far more commonplace, and will present challenges and opportunities for policy makers. 
This is a metropolitan century. Already today, more than $50 \%$ of the world's population lives in cities. This figure is projected to reach $85 \%$ by 2100 . Within 150 years, the urban population will have increased from less than 1 billion in 1950 to 9 billion by 2100. In much of Europe and North America, most of the urbanisation and basic city forms have already been set. Developing and emerging countries, however, have an unprecedented window of opportunity to shape their urban futures.

If the world is to meet ambitious goals, we need to work with cities. Whether it is for meeting the UN targets of limiting global warming or achieving the 17 Sustainable Development Goals, cities must be front and centre of our efforts. Now more than ever, the world needs to understand urbanisation and its consequences for economic, social and environmental performance, and the New Urban Agenda of Habitat III in October 2016 can become a milestone by setting the agenda for the next 20 years.

Cities strongly influence the prosperity and well-being of city residents as well as people in rural areas. As such, they should be a national policy priority.

Workers in cities have higher productivity and wages, an effect that increases with city size. With the right approach, cities can therefore contribute to productivity growth, even in less advanced countries. Non-urban regions, particularly those close to large cities, tend to be more prosperous and record higher economic growth than regions that are more remote. There are many reasons for this, but even smaller cities are important for rural areas by serving as market towns and centres of service provision.

Cities do not operate in isolation; they are part of a system of cities. OECD countries with multiple large cities, such as Germany, instead of concentration in one or two dominant cities, tend to have higher per capita GDP. After all, a larger number of major metropolitan areas means a greater part of the national territory can benefit from proximity to a major city. Moreover, the presence of several big cities may reduce the likelihood that a shock in any one place seriously hurts national performance. Furthermore, in Europe where cities tend to be smaller, it is possible to replicate some of the productivity bonus of big cities by being well connected instead. In our metropolitan age, interconnected cities are therefore key.

Still, some cities struggle to realise that potential in terms of prosperity, innovation and well-being. Even some large OECD cities-such as Birmingham or Detroit-underperform their national economies. During the dozen years up to the global financial crisis, 15 of the worst performing OECD regions in terms of growth were predominantly urban. 
There is also the particular challenge of addressing inequality within cities. Large cities are often characterised by highly successful business districts alongside pockets of very high unemployment and even poverty. Inequality between rich and poor tends to be higher in larger cities, and this gap appears to have widened in recent decades. In other words, policies to address inequality should also focus on cities .

But policies should not only focus on the problems but consider the potential of cities, too. Policies all too often target only what are deemed to be particularly "problematic" cities or neighbourhoods. The broader needs of cities are often catered to, including the role they can play in the national (and indeed international) economy.

\section{Setting the right policy frameworks}

National policies have a profound impact on cities, and must be increasingly seen through an "urban lens". National urban policy frameworks need to consider the wider range of policies that are important for cities, not only those labelled "urban". Given the large number of ministries with portfolios that influence city development, many countries have inter-ministerial committees to improve dialogue on urban issues. Typically these should include transport, housing, economy, finance and the environment.

National governments establish most of the ground rules for cities. National (and, in some federal systems, state/ provincial) legislation typically defines city responsibilities, powers and, crucially, revenue sources. Attention to the basic legislative framework for cities is essential but is too often overlooked, even though these frameworks influence, if not determine, what a mayor can do and what incentives he has to proceed.

The trouble is, different strands of policy often work at cross-purposes with one another. For example, property tax systems in many OECD countries may favour single-family homes over multi-occupancy dwellings or owner-occupied housing over rental accommodation. The evidence shows that preference for single-family units stimulates costly sprawl, while privileging home ownership tends to reduce labour-market efficiency. Both have impacts on inequality. Moreover, such tax systems can undermine other national and city-level policies intended to curb sprawl, improve labour-market efficiency and reduce inequalities.

Another issue is fragmentation of government. In the Paris region they call it the "mille-feuilles", after a famous multi-layered custard pastry. Or take the greater Chicago tri-state metropolitan area, for example, which is home to no fewer than 1,700 governmental authorities of various kinds. Even relatively modest-sized metropolitan areas are often quite fragmented. This not only makes policy making difficult, but hurts both productivity and inclusiveness, as narrow 
interests are often privileged over the common good and weaker interests are easily overlooked. For a given population size, a metropolitan area with twice the number of municipalities is found to miss out on $6 \%$ of its potential economic productivity (each year). Some of this loss can be mitigated if institutions such as metropolitan authorities can ensure certain important decisions are taken in the interest of the whole metropolitan area. However, setting up such crossjurisdictional institutions may require new legislation or wider government incentives and support.

National governments can therefore play a crucial role in devising better policies for cities if they have a coherent framework in place to help them. Different cities and countries will have different needs depending on their development levels, structure and preferences, but all countries should at least examine the urban impact of their policies, not just in areas such as national transport infrastructure planning and the environment, but in policy domains often left to cities but in which national governments typically intervene, such as housing. In short, coherent national urban policies can not only help to make our cities prosperous, livable, inclusive and sustainable, but our countries and our planet too.

\section{References}

The Metropolitan Century http://dx.doi.org/10.1787/9789264228733-en

OECD Regional Outlook 2014 http://dx.doi.org/10.1787/9789264201415-en

Habitat III Policy Unit 3 (2016), Policy Paper on National Urban Policy http:// www.habitat3.org/

OECD National Urban Policy Reviews http://www.oecd-ilibrary.org/fr/urbanrural-and-regional-development/oecd-urban-policy-reviews_23069341 